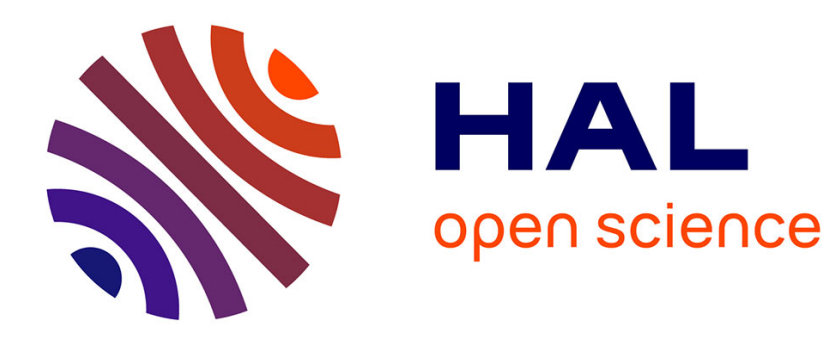

\title{
Bauschinger- and $\mathrm{X}-\mathrm{Y}$ tests on $\mathrm{Cu}$ specimens
}

F. Hess, A.W. Sleeswyk

\section{To cite this version:}

F. Hess, A.W. Sleeswyk. Bauschinger- and X-Y tests on Cu specimens. Revue de Physique Appliquée, 1988, 23 (4), pp.691-692. 10.1051/rphysap:01988002304069100 . jpa-00245840

\section{HAL Id: jpa-00245840 https://hal.science/jpa-00245840}

Submitted on 1 Jan 1988

HAL is a multi-disciplinary open access archive for the deposit and dissemination of scientific research documents, whether they are published or not. The documents may come from teaching and research institutions in France or abroad, or from public or private research centers.
L'archive ouverte pluridisciplinaire HAL, est destinée au dépôt et à la diffusion de documents scientifiques de niveau recherche, publiés ou non, émanant des établissements d'enseignement et de recherche français ou étrangers, des laboratoires publics ou privés. 


\section{BAUSCHINGER- AND X-Y TESTS ON Cu SPECIMENS}

F. Hess and A.W. Sleeswyk

Laboratorium voor Algemene Natuurkunde, Westersingel 34, 9718 CM Groningen The Netherlands

\section{INTRODUCTION}

The effects of a change in the strain direction by $90^{\circ}$ ( $x-y$ tests) or $180^{\circ}$ (Bauschinger tests) $[1,2]$ on strain hardening in polycrystalline copper at room temperature was investigated. Earlier, we calculated the shear stresses in the material for $x-y$ tests, from which it was deduced that many of the mobile dislocations reverse their paths upon the $90^{\circ}$ change in strain direction. The prediction was verified by in situ tests in the HVEM [3]. We now carried out macroscopic $x-y$ tests, in which the specimen was first strained in the $x$-direction, then unloaded, then strained in the y-direction. The results are compared to the outcome of a simple phenomenological model.

\section{THE SAMPLES}

Specimens were prepared from one sheet of commercial copper (thickness $10 \mathrm{~mm}$ ), in such a way that the strain direction in the experiments is at $45^{\circ}$ to the rolling direction of the material. The specimens for compression-tension tests are cylindrical, with gauge diameter $4 \mathrm{~mm}$ (cross section $12.6 \mathrm{~mm}^{2}$ ) and gauge length $17 \mathrm{~mm}$. Those for the $x-y$ tests are lozenge-shaped plates with gauge thickness $2 \mathrm{~mm}$ (cross section 1st test $\cong 112 \mathrm{~mm}^{2}$, 2nd test $\cong 52 \mathrm{~mm}^{2}$ ) and gauge length $28.3 \mathrm{~mm}^{2}$. These samples are pre-machined, annealed for one hour in vacuum at $550^{\circ} \mathrm{C}$, finished, and again annealed in the same way.

In the $x-y$ tests, the angle between the grips and the strain direction is $45^{\circ}$. Thus the presence of the grips has 1ittle influence on the lateral contraction, which makes for a homogeneous strain throughout the gauge section of the sample. After finishing the first part of an $x-y$ test, the sample is carefully machined to the smaller size required for the second tensile test in transverse direction.

\section{RESULTS}

The experiments were performed at a strain rate $\dot{\varepsilon}=2 \times 10^{-4} \mathrm{~s}^{-1}$. Figure 1 shows some results for specimens that were pre-strained to a stress $\sigma_{p}=80,100,120 \mathrm{MPa}$ respectively. We found that the differences in strain hardening behaviour are indicated most sensitively by the quantity $\mathrm{d} \varepsilon / \mathrm{d} \sigma\left(=\theta^{-1}\right)$. Here $\varepsilon$ is the true plastic strain and $\sigma$ the true stress MPa. The curves were obtained in tensile straining. Curves $A$ are for a sample monotonically strained to $\varepsilon=.12$. Curves $B$ are for samples that were previously strained in compression, and curves C for samples previously strained in transverse tension. Measurements like these indicate that the 'Bauschinger effect' in $\mathrm{x}-\mathrm{y}$ tests is about half as strong as in compressiontension tests.
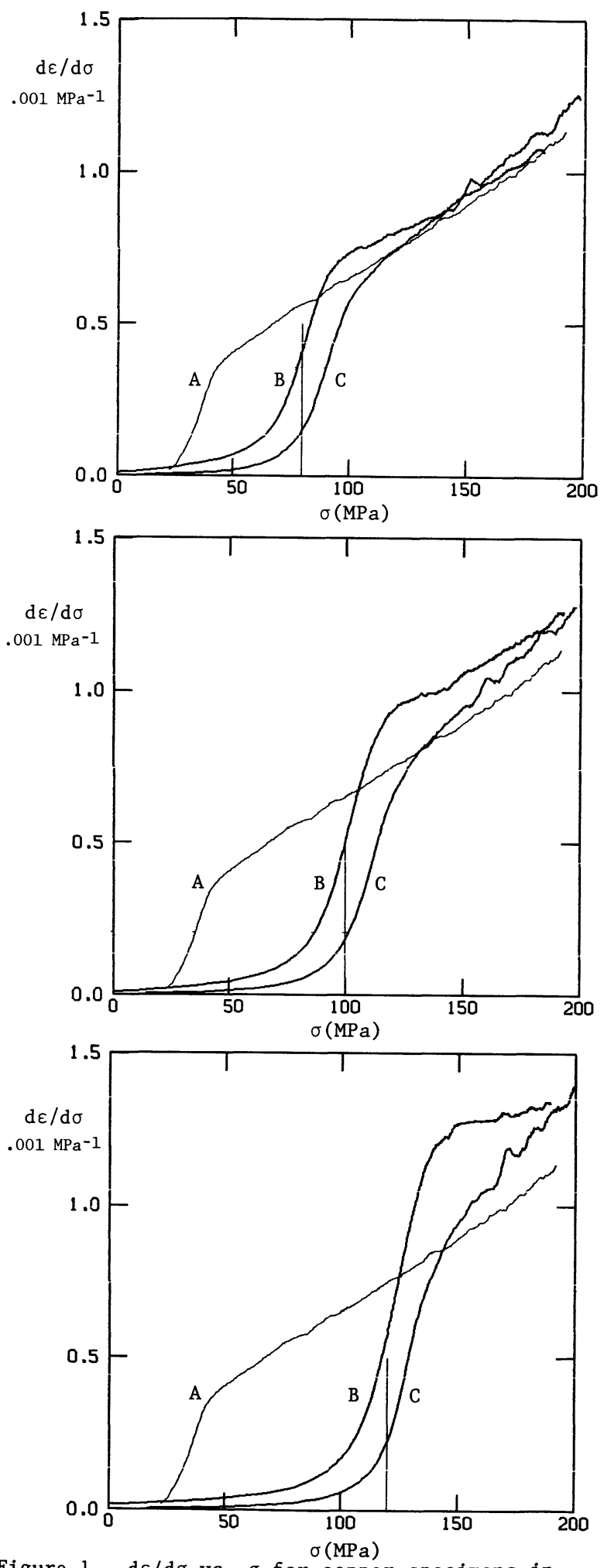

Figure 1. d $\varepsilon / d \sigma$ vs. $\sigma$ for copper specimens in tensile strain. A) monotonic strain to $\varepsilon=.12$. B) after pre-strain in compression. C) after prestrain in transverse tension and unloading.

Vertical lines indicate pre-stress $\sigma_{\mathrm{p}}$. 
MODEL

We devised a phenomenological computer model based on a few simple considerations, similar to those employed by several other investigators $[4,5,6]$, which can account for the observed partial reversibility of strain hardening.

The sample is considered as a composite (Masing mode1) with a continuous dislocation-density distribution. Everywhere in the material the total (elastic + plastic) strain is the same. The local critical tensile stress $\sigma_{c}$ at which the material deforms plastically is given by:

$$
\sigma_{c}=\sqrt{s}
$$

where $\mathbf{s}$ is proportional to the local dislocation density. Initially we have $s(v)=s_{0}(v)$, where $v$ is the volume fraction, $0 \leqq v \leqq 1$. For $s_{0}$ (v) we take the simple expression:

$$
s_{0}(v)=b+m \cdot v p
$$

$\mathrm{b}, \mathrm{m}$ and $\mathrm{p}$ being adaptable parameters. The dislocation density increases linearly with the plastic strain $\varepsilon_{\mathrm{p}} \ell$

$$
\Delta s=h \cdot \Delta \varepsilon p l
$$

where $\mathrm{h}$ is a constant hardening parameter.

The additional dislocations are taken to be reversible up to a certain limit. After strain reversal, the new dislocations annihilate the reversible fraction, so that the density and hence $\sigma_{c}$ first decrease, and then increase while a new surplus of dislocations of opposite sign is built up. It seems likely [6] that reversible dislocations tend to pile up near walls, i.e. in regions with high gradients in dislocation density. Our model cannot take care of such gradients, therefore we use the slope of the $s(v)$ curve, and assume the maximum reversible dislocation density to be

$$
r \cdot \frac{d s}{d v}
$$

where $r$ is a constant.

In $x-y$ tests the sample is first strained in the $x$-direction, then unloaded, then strained in the $y$-direction. In our model we make the assumption that the set of potential glide systems activated in $x$-strain and the set of those activated in $y$-strain overlap for $50 \%$. Therefore we assume that only half of the above mentioned reversible dislocations can be reversed in transverse straining. Figure 2 shows some results computed with:
Young's modulus

$E=1.1 \times 10^{5} \mathrm{MPa}$

for $s_{0}(v)$

$\left\{\begin{array}{l}\mathrm{b}=100 \mathrm{MPa}^{2} \\ \mathrm{~m}=10^{5} \mathrm{MPa}^{2} \\ \mathrm{p}=20\end{array}\right.$

hardening parameter

$\mathrm{h}=3.3 \times 10^{5} \mathrm{MPa}^{2}$

reversible parameter

$$
\mathrm{r}=0.04
$$

Our simple model yields some qualitative agreement with the experiments. For better results, however, the model should be extended to deal explicitly with the various slip systems in differently orientated grains [7].

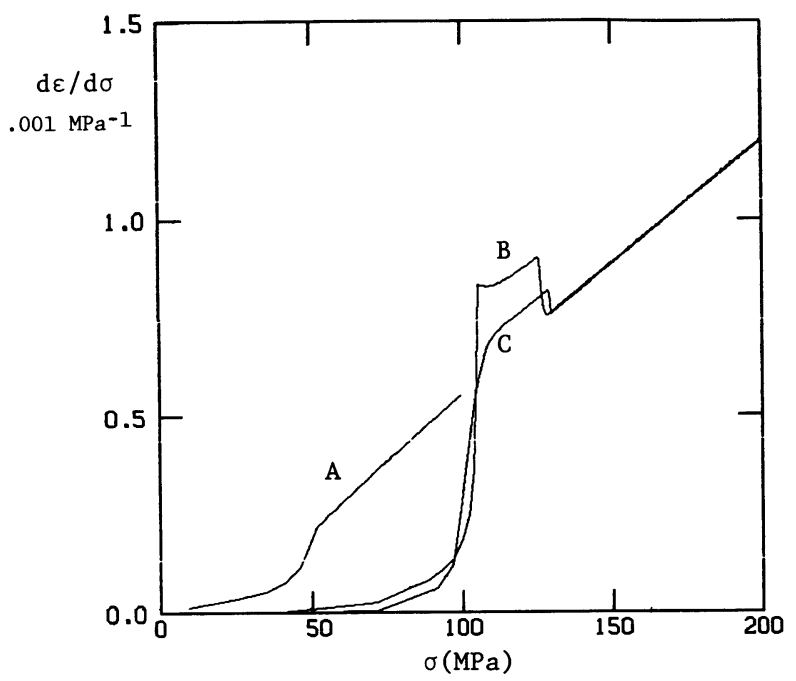

Figure 2. Model computation of $\mathrm{d} \varepsilon / \mathrm{d} \sigma$ vs. $\sigma$ A) to $\sigma=\sigma_{p}\left(\sigma_{p}=100 \mathrm{MPa}\right)$, B) after compression to $\sigma=\sigma_{\mathrm{p}}, \mathrm{C}$ ) after transverse tension to $\sigma=\sigma_{\mathrm{p}}$ and unloading.

\section{REFERENCES}

[1] Sleeswyk, A.W., Kemerink, G.J., Scripta Metal2. 19 (1985) 471.

[2] Christodoulou, N., Woo, O.T., MacEwan, S.R., Acta MetaZl. 34 (1986) 1553.

[3] Kassner, M.E., Sleeswyk, A.W., Echer, C.J., J. Electron Microscopy Technique 5 (1987) 189.

[4] Mughrabi, H., Acta Metall. 31 (1983) 1367.

[5] Bate, P.S., Wilson, D.v., Acta Metall. 34 (1986) 1097.

[6] Hasegawa, T., Yakou, T., Kocks, U.F., Mater. Sci. Engng. 81 (1986) 189.

[7] Cailletaud, G., this issue 